\title{
PERFORMANȚELE SOIURILOR-CLONE DE LAVANDĂ (Lavandula angustifolia MILL.)
}

\author{
Butnaraş Violeta, Gonceariuc Maria, Balmuş Zinaida, Botnarenco Pantelimon \\ Institutul de Genetică, Fiziologie şi Protecţie a Plantelor, Chişinău, Republica Moldova \\ e-mail: violeta.butnaras@igfpp.md
}

\begin{abstract}
The varieties of L. angustifolia created are differ by terms of technical maturation: early Moldoveanca 4, Favoare); (intermediates - Vis Magic 10, Aroma Unica); (late-Alba 7 and Svetlana). They are distinctive by a string of quantitative and qualitative characters (plant size, bush shape, inflorescence length, corolla color, floral spike length, floral stem length, number of floral stems, etc.). The productivity of these clone varieties varies depending on the annual cultivation conditions from $5.2 \mathrm{t} / \mathrm{ha}$ to $10.4 \mathrm{t} / \mathrm{ha}$ raw material production and $75-179 \mathrm{~kg} / \mathrm{ha}$ essential oil production.
\end{abstract}

Key words: Aromatic plant, variety-clones, essential oil, inflorescences, productivity.

\section{Introducere}

În Republica Moldova plantele aromatice şi medicinale se cultivă din anul 1948. Importanţa acestora este incontestabilă, deoarece este cunoscut faptul că, succesele deosebite realizate de chimia organică în sinteza unei game largi de medicamente nu au diminuat importanţa remediilor din plante. $\mathrm{Cu} 10$ ani în urmă $45 \%$ din medicamentele produse erau de origine vegetală sau conţineau compuşi organici din plante medicinale. Din numeroasele specii de plante aromatice şi medicinale un loc important îi revine levănţicăi - Lavandula angustifolia care este o specie valoroasă pentru agricultura şi economia Republicii Moldova. În prezent rata produselor medicamentoase din plante medicinale şi aromatice este în creştere. Prin lucrări de ameliorare s-au creat genotipuri, forme, hibrizi, soiuri, de lavandă în care corelaţia dintre anumiţi compuşi este mai favorabilă pentru utilizarea acestora în formă de infuzii, extracte sau pentru folosirea în industria de procesare a materiei prime aromatice, farmaceutice.

În prezent ţara noastră este un exportator important de uleiuri esenţiale, extracte şi materie primă fitofarmaceutică de lavandă. Calitatea produselor fabricate în R.Moldova este net superioară datorită, in primul rând, soiurilor distinse prin productivitate sporită, rezistenţă la factori biotici şi abiotici, perioadă diferită de recoltare, corelaţie inedită a componenţilor principali în uleiul esenţial.

Începând cu anul 2009 a crescut cererea la materialul săditor şi la uleiul esenţial de levănţică (Lavandula angustifolia Mill.). Cercetările includ evaluarea celor mai perspective soiuri de Lavandula angustifolia Mill. cu caractere cantitative remarcabile, ce prezintă interes pentru producătorii şi firmele specializate care se ocupă cu cultivarea speciei menţionate.

Soiurile-clone create şi propuse se deosebesc prin rezistentă sporită la ger, iernare şi secetă, boli şi productivitate înaltă. $[1,4]$.

\section{Materiale şi metode}

În calitate de material iniţial pentru crearea soiurilor au servit descendenţii generativi de provenienţă genetică şi geografică diferită, obţinuţi prin hibridări policross si selectaţi după caracterele cantitative şi calitative valoroase. Soiurile de lavandă (Lavandula angustifolia Mill.), create şi omologate în R. Moldova reprezintă hibrizi de prima generaţie $F_{1}$ care manifestă heterozis la caracterele cantitative, asigură $o$ producţie înaltă de materie primă, conţinut ridicat de ulei esenţial de calitate superioară. Primăvara devreme la soiurile create şi aflate în studiu s-a determinat rezistenţa la iernare şi ger, prin evaluarea numărului de lăstari per plantă îngeţaţi, s-a apreciat şi notat de la 1 până la 5 baluri. Evaluări fenologice prin notarea calendaristică a fazelor de dezvoltare [3, 6, 7]. Evaluări biomorfologice (valoarea caracterelor cantitative, ce asigură productivitatea - număr tulpini florale per plantă, lungimea inflorescenţei, spicului, tijei florale, număr verticile per spic floral ) conform Ghidului UPOV şi metodelor în vigoare $[3,10]$. Determinarea potenţialului de producţie a materiei prime - prin recoltarea fiecărui soi în 4 repetiţii; cântărirea, prelevarea mostrelor pentru determinarea umidităţii, conţinutului de ulei etc. [2]. 
Metode de laborator: separarea uleiului esenţial prim hidrodistilare în aparate Ginsberg şi Clevenger din mostre de inflorescenţe proaspete prelevate în faza înfloririi depline a speciei, în orele de dimineaţă; determinarea conţinutului în ulei; determinarea gradului de umiditate a mostrelor de plante şi recalcularea conţinutului în ulei la umiditate standard (60\%) şi la substanţă uscată [3].

Interpretarea statistică a datelor experimentale obţinute s-a efectuat conform metodelor în vigoare [2,9] şi cu ajutorul softului STATISTICA 7.

\section{Rezultate şi discuţii}

În cadrul Institutului de Genetică, Fiziologie şi Protecţie a Plantelor, în Laboratorul „Plante Aromatice şi Medicinale" sub conducerea doctorul habilitat în ştiinţe agricole, Maria Gonceariuc au fost create şi omologate soiurile de levănţică: Moldoveanca 4, Alba 7, Vis Magic 10, Aroma Unica, Favoare şi Svetlana. Aceste soiuri au un randament înalt al producţiei de inflorescenţe şi conţinut sporit de ulei esenţial, sunt distinctive după un şir de caractere cantitative şi calitative. Dintre acestea pot fi menţionate dimensiunile plantei, caracterul pubescenţei frunzelor, forma tufei, lungimea inflorescenţei, culoarea corolei, lungimea spicului floral, lungimea tijei florale, numărul de tulpini florale etc. Soiurile create se deosebesc şi prin termenii de înflorire (timpurii, intermediare şi tardive) $[1,4,5,8]$. Productivitatea acestor soiuri-clone variază în funcţie de condiţiile de cultivare anuale sau depăşeşte soiurile-clone create anterior.

Soiurile de levănţică sunt pretabile pentru cultivarea şi recoltarea mecanizată. Descrierea morfologică, siccintă a soiurilor-clone este în anul al IV-lea de vegetaţie:

\section{Soiul MOLDOVEANCA 4}

Subarbust cu talia de 58,5 cm, diametrul plantei - 107,7 cm; numărul de tulpini florale la o plantă 557 unităţi. Frunzele opuse, sesile, liniar-lanceolate, pubescente de culoare verde-gri; inflorescenţa - spiciformă, lungimea de $26,3 \mathrm{~cm}$, cu spicul floral $-7,9 \mathrm{~cm}$, tija florală de $18,4 \mathrm{~cm}$ cu flori grupate în $6-7$ pseudoverticile. Florile au caliciul tubular de culoare violacee şi corola violet-închis. Fructul - nucule (seminţe) mici, netede, lucioase, brune. Masa a 1000 de seminţe constituie 0,6g. Domeniul de utilizare a soiului respectiv - producerea uleiului esenţial şi a materiei prime farmaceutice [3,4]. Grupa de maturitate - timpurie. Producţia medie de inflorescenţe: - 5,2 t/ha. Producţia medie de ulei esenţial: $75 \mathrm{~kg} / \mathrm{ha}$. Randamentul de ulei esenţial de $19-21 \mathrm{~kg} / \mathrm{t}$.

Avantajele soiului Moldoveanca 4 sunt: rezistent la ger şi iernare, la secetă, boli [1,4]. Soiul menţionat este omologat în anul 2005 în Republica Moldova, în anul 2017 în România.

\section{Soiul ALBA 7}

Subarbust cu talia de 52,7 cm, diametrul - 99,8 cm. Numărul de tulpini florale per plantă constituie 675 unit. Frunzele opuse, sesile, liniar-lanceolate, pubescente de culoare verde-gri. Inflorescenţa - spiciformă, cu lungimea de $(21,3 \mathrm{~cm})$, spicul floral de $7,7 \mathrm{~cm}$, tija florală $-13,6 \mathrm{~cm}$. Numărul de verticilii pe spicul floral este de 6,5 unităţi. Florile până la deschidere au caliciul şi butonul floral alb, iar la deschiderea florii corola este de culoare violet-albăstrie deschis. Fructul - nucule(seminţe) mici, netede, lucioase, brune. Masa a 1000 de seminţe constituie 0,6 g. Grupa de maturitate - tardiv. Producţia medie de inflorescenţe: - 7,4 t/ha. Producţia medie de ulei esenţial: $129 \mathrm{~kg} / \mathrm{ha}$. Randamentul de ulei esenţial de 19$21 \mathrm{~kg} / \mathrm{t}$. Avantaje: Rezistent la ger şi iernare, la secetă, boli [4, 8]. Soiul Alba 7 este omologat în anul 2005 în Republica Moldova, în anul 2018 în România.

\section{Soiul VIS MAGIC 10}

Semiarbust cu talia de 63,3 cm, diametrul $-111,5 \mathrm{~cm}$, tulpini florale 715,7. Frunzele - opuse, sesile, liniar lanceolate, pubescente; verzi-gri; inflorescenţa spiciformă cu lungimea de $(25,6 \mathrm{~cm})$, tija florală - 15,7 $\mathrm{cm}$. Florile sunt grupate în 7,3 pseudoverticile, au caliciul verde violaceu, pubescent, iar corola este de culoare violaceu-albastru închis. Fructul - nucule (seminţe) mici, netede, lucioase, brune. Masa a 1000 de seminţe constituie 0,6g. Destinaţia soiului este producţia de ulei esenţial şi de materie primă farmaceutică. Este un soi bun pentru cultivare şi recoltare mecanizată, precum şi pentru procesarea industrială $[4,8]$. Grupa de maturitate - medie Producţia medie de inflorescenţe: - 6,5 t/ha .Producţia medie de ulei esenţial: 83,3 kg/ha. Randamentul de ulei esenţial de 17-20 kg/t. Avantaje: Rezistent la ger şi iernare, la secetă, boli. [4]. Soiul menţionat este omologat în anul 2005 în Republica Moldova, în anul 2017 în România. 


\section{Soiul AROMA UNICA}

Planta este un semiarbust peren, cu talia de $67,7 \mathrm{~cm}$, diametrul plantelor $-139,1 \mathrm{~cm}$ şi cu 1740 tulpini florale per plantă de formă compactă. Florile până la deschidere au caliciul şi butonul floral de culoare albastră-deschis, corola în interior este violet - albăstruie. Inflorescenţa - spiciforme, lungă $(25,4$ $\mathrm{cm}$ ), spicul floral de $13,1 \mathrm{~cm}$, tija florală $-12,3 \mathrm{~cm}$ cu flori grupate în 8,3 pseudoverticile. Fructul este de formă alungită, netedă, lucioasă de culoare brună. $\mathrm{MMB}=0,7 \mathrm{~g}$. Direcţia de producţie este fabricarea uleiului esenţial, produs farmaceutic, condiment. Grupa de maturitate - mediu. Producţia medie de inflorescenţe: $-10,4$ t/ha. Producţia medie de ulei esenţial: $166 \mathrm{~kg} / \mathrm{ha}$. Randamentul de ulei esenţial de 18-20 kg/t. Soiul Aroma Unica este omologat în anul 2019 în Republica Moldova.

\section{Soiul FAVOARE}

Planta este un semiarbust peren, care face parte din grupul de maturitate timpurie, perioada de vegetaţie de 60 zile. Talia plantei de $68,0 \mathrm{~cm}$, diametrul plantei $-91,3 \mathrm{~cm}$ de formă răsfirată cu 835 tulpini florale. Frunzele soiului menţionat sunt de culoare verde-deschis. Forna frunzelor este liniară. Caliciul este de culoare verde-violaceu, corola violet-deschisă. Spicul floral de $8,5 \mathrm{~cm}$. Florile sunt grupate în 6-7 pseudoverticile. Lungimea tijei florale de $25,5 \mathrm{~cm}$, pretabilă la recoltarea manuală şi mecanizată. Fructul se împarte în 4 nucule de culoare brune, cu masa a 1000 de seminţe de $0,7 \mathrm{~g}$. Conţinut în ulei esenţial, la umiditatea standard (60\%) - 2,077\%, la substanță uscată $-5,157 \%$. Producţia medie de inflorescenţe: $-7,4$ t/ha. Producţia medie de ulei esenţial: 155,2 kg/ha. Randamentul de ulei esenţial de 20,7 kg/t. Soiul timpuriu Favoare este apreciat cu o rezistenţă înaltă la ger şi iernare, a fost testat în culturi comparative de concurs. Este depusă cerere de Brevet la AGEPI, (v 20210007 din 22.02.2021) şi cerere de înregistrare în Registrul de Stat CSTSP (nr. 0664913 din 23.02.2021).

\section{Soiul SVETLANA}

Planta este un semiarbust peren, care face parte din grupul de maturitate tardivă, perioada de vegetaţie de 71 zile. Forma tufei sferică, inflorescenţa alungit-cilindrică. Corola florii este violet închisă, caliciul violet închis cu pubescenţă. Frunzele sunt alungit-lanceolate cu nervuri longitudinale de culoare verde închisă. Talia plantei variază în dependenţă de condiţiile climaterice ale anului până la $71,5 \mathrm{~cm}$. Diametrul plantei în mediu este de $93,3 \mathrm{~cm}$. Numărul de tulpini florale per/plantă - 854. Lungimea tijei florale $-22,8 \mathrm{~cm}$. Lungimea spicului $-9,5 \mathrm{~cm}$. Numărul de verticile în infloriscenţă $-7,9$ unităţi. Masa a 1000 de seminţe constituie 0,7g. Conţinut în ulei esenţial la umiditatea standard (60\%) - 2,323\%, la substanţă uscată - 5,721\%. Producţia medie de inflorescenţe: $-7,7$ t/ha. Producţia medie de ulei esenţial: $179,2 \mathrm{~kg} / \mathrm{ha}$. Randamentul de ulei esenţial de $23.4 \mathrm{~kg} / \mathrm{t}$. Soiul menţionat este apreciat cu o rezistenţă înaltă la ger şi iernare de 5.0 puncte. Este depusă Cerere de Brevet la AGEPI, (v 20210006 din 22.02.2021) şi Cerere de înregistrare în Registrul de Stat CSTSP (nr. 0664912 din 23.02.2021).

\section{Concluzii}

1. Soiurile de L. angustifolia create se deosebesc prin termeni de maturizare tehnică: (timpurii- Moldoveanca, Favoare); (intermediare - Vis Magic 10, Aroma Unica); (tardive-Alba 7 şi Svetlana), au un randament înalt al producţiei de inflorescenţe şi conţinut sporit de ulei esenţial.

2. Sunt distinctive după un şir de caractere cantitative şi calitative (dimensiunile plantei, forma tufei, lungimea inflorescenţei, culoarea corolei, lungimea spicului floral, lungimea tijei florale, numărul de tulpini florale etc.)

3. Productivitatea acestor soiuri-clone variază în funcţie de condiţiile de cultivare anuale de la 5,2 t/ha până la $10,4 \mathrm{t} / \mathrm{ha}$ producţia materie prima şi de $75-179 \mathrm{~kg} / \mathrm{ha}$ producţia ulei esenţial

4. Direcţia de producţie a acestor soiuri este fabricarea uleiului esenţial prin hidrodistilare (parfumerie, aromaterapie); industria alimentară, produs farmaceutic, plantă meliferă, antierozională, decorativă.

5. Avantajele soiurilor sunt: Rezistente la ger şi iernare, secetă, boli.

Cercetările au fost realizate în cadrul proiectului Programului de Stat 20.80009.5107.07 "Diminuarea consecinţelor schimbărilor climatice prin crearea, implementarea soiurilor de plante medicinale şi aromatice cu productivitate înaltă, rezistente la secetă, iernare, boli, ce asigură dezvoltare sustenabilă a agri- 
culturii, garantează produse de calitate superioară, predestinate industriei de parfumerie, cosmetică, farmaceutică, alimentară”, finanțat de Agenția Națională pentru Cercetare și Dezvoltare.

\section{Bibliografie}

1. BUTNARAŞ, V., GONCEARIUC, M., BALMUŞ, Z., ş.a. Soiurile de Lavandula angustifolia Mill, create şi omologate în Republica Moldova. În: Agrobiodiversitatea vegetală în Republica Moldova: evaluarea, conservarea şi utilizarea : materialele simpoz. naţ., 26-27 iun. 2008. Ch., 2008, p. 241-243. ISBN 978-99-62-230-1.

2. CEAPOIU ,N., POTLOG, A. S. Ameliorarea plantelor agricole. Bucureşti : Edit. Agro-Silvică, 1990. $484 \mathrm{p}$.

3. GONCEARIUC, M. Lavanda. Ameliorarea plantelor eterooleaginoase. În: Ameliorarea specială a plantelor agricole. Ch.: Tipografia Centrală, 2004, p. 542-552.

4. GONCEARIUC, M., BALMUŞ, Z. Soiuri de Levănţică (Lavandula angustifolia Mill.) rezistente la iernare şi ger. In: Probleme actuale ale geneticii, biotehnologiei şi ameliorării : materialele conf. naţionale (jubiliare) cu participare internaţională, 17-18 febr. 2005. Ch., 2005, p. 262-265.

5. GONCEARIUC, M., BALMUŞ, Z. Lavender (Lavandula angustifolia Mill.) varietes-clones. In: EUROINVENT-2014 Catalogue / Edit. Alexandru Ioan Cuza University Publishing House. Yassy, 2014, p. 136-137. ISBN 978-606-714-037-8.

6. Lavanda (Lavandula angustifolia Mill.). În: MUSTEAŢĂ G. Subarbuşti medicinali şi aromatici cultivaţi. Ch., 2007, p. 6-24. ISBN 978-9975-946-59-9.

7. PĂUN, E. Lavanda (Lavandula angustifolia Mill). În: Sănătatea Carpaţilor. Bucureşti, 1995, p. 129-133.

8. *** Registrul Soiurilor de Plante al Republicii Moldova. Ediţie oficială. Ch. 2005.

9. ДОСПЕХОВ, Б.А. Методика полевого опыта (с основами статистической обработки результатов исследований). М.: Агропромиздат, 1985. 351 с.

10.РОМАНЕНКО, Л.Г. Лаванда. Селекция эфиромасличных культур: метод. указ. Симферополь: ВНИИЭМК, 1977, 64 с. 